\title{
Potential of biofertilisers to improve performance of local genotype tomatoes
}

\author{
Carmen Puia, ${ }^{1}$ Roxana Vidican, ${ }^{2}$ Gyöngyi Szabó, ${ }^{1}$ Vlad Stoian ${ }^{2}$ \\ ${ }^{1}$ Department of Plant Pathology, University of Agricultural Sciences and Veterinary Medicine Cluj-Napoca, \\ Cluj-Napoca; ${ }^{2}$ Department of Microbiology, University of Agricultural Sciences and Veterinary Medicine \\ Cluj-Napoca, Cluj-Napoca, Romania
}

\begin{abstract}
Complex microbial communities in the plant rhizosphere are responsible for their success in ecosystems. Supplementary inoculation of soil with mycorrhizal fungi and rhizospheric bacteria may act as a plant growth-promoting factor. The present study aims to assess the potential use of biofertilisers on tomato as a way of increasing yield and stability of root exploration area. The experiment was set up in greenhouse, regarding the evaluation of growing dynamics of plants, mycorrhization level and obtained yield. The identification of effective inoculation variants can lead to a standardisation of technologies of growing for local plant genotypes. Data analysis was performed based on the ANOVA test, followed by Tukey HSD, principal component analysis and cluster analysis in order to identify the potential of bioproducts to stimulate the development of tomato plants. Application of bacterial biofertilisers does not stimulate enough the aboveground development of plants. An antagonistic reaction is visible between exogenous mycorrhizas and those specific in soil, acting slightly different for each genotype. Mycorrhizal level in root systems is more dependent on applied biofertilisers than on analyzed genotypes. For the variants without additional fertilisers, a high level of mycorrhization is visible only after 75 days from the transplantation. Based on results we can conclude that microbial active fertilisers may represent viable solutions to increase yield capacity and root exploration area for local tomato genotypes.
\end{abstract}

\footnotetext{
Correspondence: Carmen Puia, Department of Plant Pathology, University of Agricultural Sciences and Veterinary Medicine ClujNapoca, Calea Mănăştur 3-5, 400372, Cluj-Napoca, Romania.

E-mail: carmen.puia@usamvcluj.ro
}

Key words: Mycorrhiza; Tomatoes; Local genotype; Biofertilisers; Plant growth promoting microorganism.

Received for publication: 12 September 2016.

Revision received: 17 January 2017.

Accepted for publication: 17 January 2017.

CCopyright C. Puia et al., 2017

Licensee PAGEPress, Italy

Italian Journal of Agronomy 2017; 12:838

doi:10.4081/ija.2017.838

This article is distributed under the terms of the Creative Commons Attribution Noncommercial License (by-nc 4.0) which permits any noncommercial use, distribution, and reproduction in any medium, provided the original author(s) and source are credited.

\section{Introduction}

The vesicular-arbuscular mycorrhiza associations (AMF) are the most relevant symbiosis in ecosystems, developed after the synchronised coevolution of plants and fungi in the same environmental conditions (Bonfante and Genre, 2008; Helgason and Fitter, 2009; Montaño et al., 2012). The extra radicular hyphae increase the exploitation area of associated plants, which results in an efficient usage of the soil resources, together with the promoted growth and development (Brundrett and Ashwath, 2013; Conversa et al., 2012; Garg and Chandel, 2010; Jayne and Quigley, 2014; Koltai and Kapulnik, 2010; Lambers et al., 2009). Inoculating the soil had beneficial results in the productive ecosystems, especially when the indigenous mycorrhizal flora is not infectious or efficient enough (Hoeksema et al., 2010; Lemanceau et al., 2015; Rillig et al., 2014). The success of mycorrhizal inoculum depends on the capacity to compete for resources of alien species and the association speed with the rhizospheres plants to which these are introduced to (Garg and Pandey, 2015; Gianinazzi et al., 2010; Vicente-Sánchez et al., 2014; Watts-Williams and Cavagnaro, 2014; Wezel et al., 2014). The AMF symbiosis are reflected over the photosynthetic processes, the nutritive elements absorption and improvement of the soil properties (Fritz et al., 2006; Raviv, 2010; Shrivastava et al., 2015; Taffouo et al., 2014; Treseder, 2013).

The bacterial functional groups are vital components in the soil processes, enhancing the nutrients dynamics (Bashan et al., 2014; du Jardin, 2015; Prashar et al., 2014). Promoting the plants growth with rhizobacteria is based on the production of growth regulators, protecting the plants over the pathogen attacks and mobilising the nutrients (Ehrmann and Ritz, 2014; Lareen et al., 2016; Yang et al., 2013). Rhizobacteria sustains the plants in competition for the space inside the ecological niche, nutrients and production of phitohormones with positive impact over the environment (Abbas et al., 2014; Ahmed et al., 2014; Moënne-Loccoz et al., 2015). Currently, a high diversity of symbiotic and nonsymbiotic rhizobacteria are included in activities related to crops, with a role in reducing the negative impact of heavy metals, pesticides or soil pH (Dotaniya and Meena, 2015; Matsushita et al., 2015; Paul and Lade, 2014; Verma et al., 2014). Using the rhizobacteria in promoting the plants growth is restricted by the inoculums complexity, response of genotypes, ecosystem and dimension of pathogens populations (Barrière et al., 2014; Fahad et al., 2015; Pandya et al., 2014; Park et al., 2014).

The present study analyzes the potential of biofertilisers with AMF and rhizobacterias as an improvement for above- and belowground development of local tomatoes genotypes. Measurement of the relationship between the mycorrhizal and rhizobacterial inoculum and plants is performed in conventional and unconventional crop conditions, with the purpose to appreciate the degree of applicability and adaptability to local conditions of bioproducts 
with exogenous microflora. Identifying the variants with positive results might lead to a standardisation of local tomato crops with biofertilisers used in the global agriculture.

\section{Materials and methods}

\section{Experimental design}

The experiment was located in a greenhouse placed in ClujNapoca area, Romania (464ㅇ $\mathrm{N} / 23^{\circ} 36^{\prime} \mathrm{E} / 363 \mathrm{~m}$ altitude), in 3 repetitions, during 2014, with regards to the evaluation of the growing dynamics of plants, the mycorrhization level and the obtained yield. The air temperature was kept between $8^{\circ} \mathrm{C}$ (night) and $16^{\circ} \mathrm{C}$ (day) during plant growth in the nursery. After plant transplantation the temperature was maintained at $16^{\circ} \mathrm{C}$ (night) and $21-22^{\circ} \mathrm{C}$ (day) from June to August and with a reduction to $16^{\circ} \mathrm{C}$ during September-October. Relative humidity of air was maintained between $65-75 \%$. In the greenhouse the soil type was a chernozem on which has been applied a basic fertilisation for tomatoes with $20 \mathrm{t} /$ ha manure (Table 1). The experimental design included a combination of $3 \times 2 \times 3$ factors. The trial was organised in a completely randomised design, with four rows/variant, each variant having a length of $2.25 \mathrm{~m}$ and a width of $2.64 \mathrm{~m}$, which consist in a $5.94 \mathrm{~m} 2 /$ variant - divided in two equal parts: one for mycorrhizal traits ( 3 plants for each assay/variant) and one for yield analysis. As plant material were chosen 3 local tomato varieties: Hostati $(\mathrm{H}-$ Host), Inimă de bou (I-Inib) and Roz (R-Roz). Plants were sown in nursery on 10 March and prick out at 30 days from this date. The final transplantation in soil was performed when the plants have reached the age of 60 days. The distance between plants on row was $0.33 \mathrm{~m}$ and between rows $0.75 \mathrm{~m}$, which correspond to approximately 40000 plants/ha. The weeds were removed by hand. The irrigation of the crop was carried out with a drip hose irrigation system and an average amount of 5-6 1 water / plant every 45 days throughout the growing season. Treatments done over the vegetation period had 2 crop conditions: conventional (C-Conv Bravo 500 SC + Ridomil Gold Plus 42.5 Wp) and unconventional (N-Nconv - Bordeaux mixture + Nettle macerate). Each treatment was applied once during the vegetation period. Bravo $500 \mathrm{SC}$ $(0.2 \%$ concentration) and nettle macerate $(9 \%$ concentration) were applied at 30 days from the transplantation in the greenhouse. Ridomil Gold Plus $42.5 \mathrm{Wp}(0.3 \%$ concentration $)$ and Bordeaux mixture ( $1 \%$ concentration) were applied at 60 days from the plant transplantation. There were also 3 fertilisation levels: unfertilised + natural mycorrhization (N-Nf), supplementary mycorrhization (M-Myk) and bacterial inoculum (B-Bact).

Measurements of plants height were done over a period of 50 days, starting with the moment of transplantation. After this period, the differences of heights between variants were no longer significant. Mycorrhizal colonisation and the extent of hyphae in roots were assessed according the formulas proposed by Trouvelot (http://www2.dijon.inra.fr/mychintec/Protocole/Workshop_Proced ures.html) and completed with colonisation degree (Cdeg \%), described by Stoian et al. (2014) as the product between frequency and intensity of colonisation. It have been calculated the arbuscular percentages in mycorrhizal fragments (a \%) and in radicular system (A \%) and the degree of colonisation (Cdeg \%) as factors of mycorrhization. Assessment of the mycorrhizal parameters was performed at 15, 35, 55, 75, 95 and 115 days from transplanting, based on the coloration with blue ink of 60 root segments/ variant $(1 \mathrm{~cm} /$ segment $)$ and direct microscopy.

Plant growth was analyzed from 10 to 10 days after 20 days from transplantation, and it stopped when most of plants have reached an average size of $1.5 \mathrm{~m}$. Tomatoes were harvested starting at 60 days from transplantation in greenhouse (in July) till the end of vegetation period, at the beginning of October.

\section{Biofertilisers}

The biofertilisers were applied at the final transplanting of the plants in greenhouse, when plants had 5-7 leaves.

Mykosoil - a biofertiliser with AMF from GreenBase Company - 200 units of infection/mL of product (www.mykorrhiza.eu). Fungi present in the product were: Glomus mosseae, G. intraradices, G. clarum, G. monosporus, G. deserticola, G. brasilianum, G. aggregatum, G. etunicatum, G. fasciculatum, Gigaspora margarita. The applied dose was $10 \mathrm{~mL}$ of commercial product/plant.

Bactofil - a biofertiliser produced by Agro.bio Hungary Kft based on Azospirillium lipoferium, Azotobacter vinelandii, Bacillus megaterium, B. circulans, B. subtilis, Pseudomonas fluorescens, Micrococcus roseus, contains also macro and micro elements, biosynthetised enzymes by microorganisms, growth stimulators, vegetal hormones and vitamins (www.agrobio.hu). The applied dose was $0.002 \mathrm{~mL}$ of commercial product /plant.

\section{Analysis of experimental data}

In order to assess the singular and combined impact of experimental factors on above- and below-ground parameters we performed a three-way ANOVA test in StatSoft Statistica. The rest of experimental data was analysed with vegan (Oksanen et al., 2015), Hmisc (Harrell and Dupont, 2015) and agricolae (de Mendiburu, 2014) and cluster (Maechler et al., 2015) packages specific to the RStudio software, version 0.99.879 (RStudio Team, 2015). For identifying the connections between the experimental factors and the development under- and over ground of plants, Pearson type correlations were calculated. The dendrograms were executed separately for the above- and below-ground developments, and the resulted clusters were used as restrictive conditions in Tukey HSD test. For each type of development, above- and below-ground, the principal component analysis (PCA) was performed with the variance calculated for both of the axis.

Table 1. Soil and manure main characteristics.

\begin{tabular}{|c|c|c|c|c|c|c|}
\hline Soil & $\mathrm{pH}$ & Total N (\%) & $\mathbf{P}_{\mathrm{AL}}(\mathrm{ppm})$ & $\mathrm{K}_{\mathrm{AL}}(\mathrm{ppm})$ & Humus (\%) & Texture \\
\hline & 7.03 & 0.15 & 58 & 240 & 3.87 & Clay-loam \\
\hline Manure & Dry matter (\%) & $\begin{array}{l}\text { Total N } \\
\left(\mathrm{g} \mathrm{kg}^{-1}\right)\end{array}$ & $\begin{array}{c}\mathrm{P}_{2} \mathrm{O}_{5} \\
\left(\mathrm{~g} \mathrm{~kg}^{-1}\right)\end{array}$ & $\begin{array}{c}\mathrm{K}_{2} \mathrm{O} \\
\left(\mathrm{g} \mathrm{kg}^{-1}\right)\end{array}$ & & \\
\hline & 16.7 & 18.2 & 17.4 & 14.8 & & \\
\hline
\end{tabular}




\section{Results}

Based on the ANOVA results it is visible the strong influence of variety and biofertilisers on above-ground development of tomato plants (Table 2). The variety has a strong impact at the beginning of the growing season (D20 - F $=112.80 * * *)$ and extremely significant at 50 days after transplanting $(\mathrm{F}=$ $4540.4 * * *)$. Fluctuations in yield are only significantly influenced by variety, instead for the average of fruits this factor is very significant $(\mathrm{F}=53.82 * * *)$. Biofertilisers can be found as a very significant influence during the first two growth stages (D20 and D30) and for the fructification potential in the first and third plant floor (Et.1 and Et.3). For all the mycorrhizal parameters biofertilisers plays an important role by significantly influencing their development $\left(\mathrm{F}=15.23-212.50^{* * *}\right)$. A significant synergic effect of factors is visible only for the combination of variety and treatment (Vt*Tr) and only for the first plant floor and arbuscules in root segments at 15 days from transplantation. These results are consistent with the role of plant growth promotion by active microorganisms contained by biofertilisers, as previous reported and described by Candido et al. (2015) and Egamberdieva et al. (2015).

The general aboveground and belowground development of plants is strongly correlated with the experimental factors (Table 3). The aboveground development is a character specific to the studied varieties, while the unfertilised variants do not succeed in offering the plants the conditions to reach the potential to grow and produce. Mycorrhizal indicators are correlated negatively with the lack of fertilisation and positively with the supplementary mycorrhization. The vegetative character dendrogram indicates a reduced specificity of plants reaction to the experimental factors (Figure 1). Separating the variants in clusters is due to the interaction between the factors in a higher mean than the one of a single factor, both when dividing in 2 and also in 3 clusters. The steadiest variety is Hostati, completely present in a single cluster and maintaining the cluster's integrity even at the dendrogram's split into 3 clusters. The variety Inimă de bou has the same reaction to the conventional and unconventional treatments in the lack of fertilisation, and the vari-

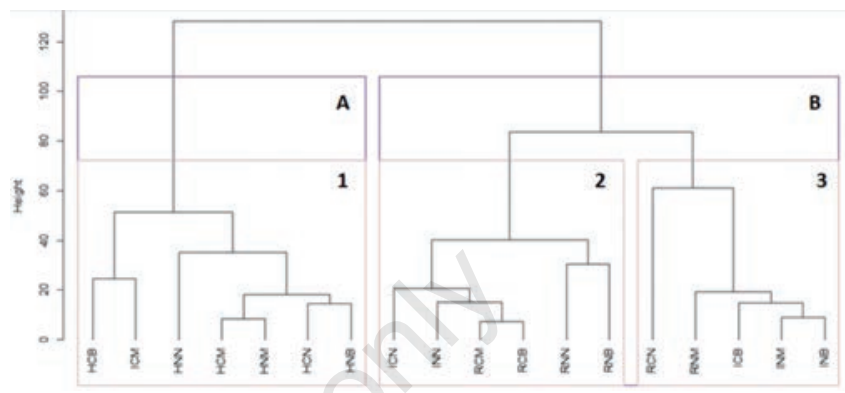

Figure 1. Dendrogram of aboveground development. Legend of code letters is as follows: first letter: $H, R, I$ - plant genotype; second letter: C, N-type of crop system; third letter: N, M, B - type of fertilisation.

Table 2. Results of three-way analysis of variance showing the effect of tomato variety, treatment and fertilisation and their interactions on above- and belowground parameters.

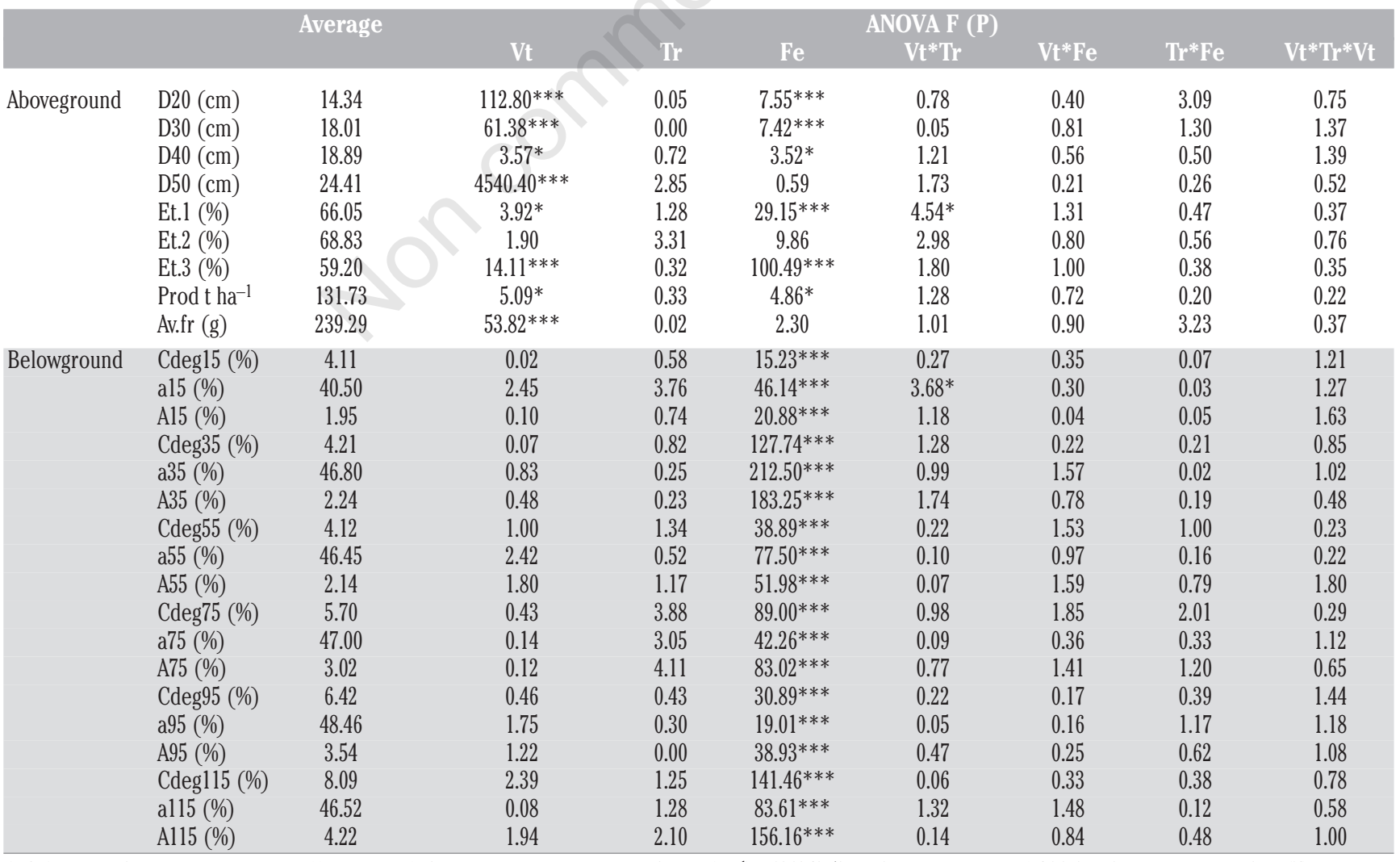

ANOVA, analysis of variance; Vt, tomato variety; Tr, treatment; Fe, fertilization; D, increase in height of plants $\left(\mathrm{cm}^{-1}\right)$ at 20,30,40, 50 days from transplantation; Et 1,2,3, fructification at each plant floor (\%); Prod, production ( $\mathrm{t} \mathrm{ha}{ }^{-1}$ ); Av.fr, average mass of tomatoes fruits (g); a, A, Cdeg, mycorrhizal parameters (\%); 15, 35, 55, 75, 95, 115 - days from plantation. ${ }^{*} \mathrm{P}<0.05 ;{ }^{* *} \mathrm{P}<0.01 ;{ }^{* * *} \mathrm{P}<0.001$. 
ety $\operatorname{Roz}$ has a similar reaction to bacterial inoculation and mycorrhization overposed to the conventional treatments, respectively bacterial doses and the lack of fertilisation in conditions of unconventional crop. Cluster 1 is characterised by a weak development of plants in the first 30 days after transplantation, with significant differences over the other 2 clusters (Table 4). Starting with 40 days after transplantation, the differences between the variants included in the 3 clusters are reduced and maintained at an insignificant level over the entire vegetation period. At the level of development stages, the differences between the clusters are significant only at stage 3 , the variants specific to the cluster 2 having a development plus. The production holds the same constant differences between the clusters at the level of development stage 3, but are not perfectly fit onto the average observed for the fruits weight. The above-ground development of plants is a character imposed especially by the variety and amplified by the applied fertilisations, the total of variance is $81 \%$ (PC1 56.21\% and PC2 $24.83 \%$ ) in the analysed experimental conditions (Figure 2, Table 5). A specific reaction is noticed for the Hostati variety, while the Roz and Inimă de bou varieties are overlapped as reaction. In the analysed interaction, the variety has the highest impact on the above-ground development.

Variance of mycorrhization parameters highlights the effect of

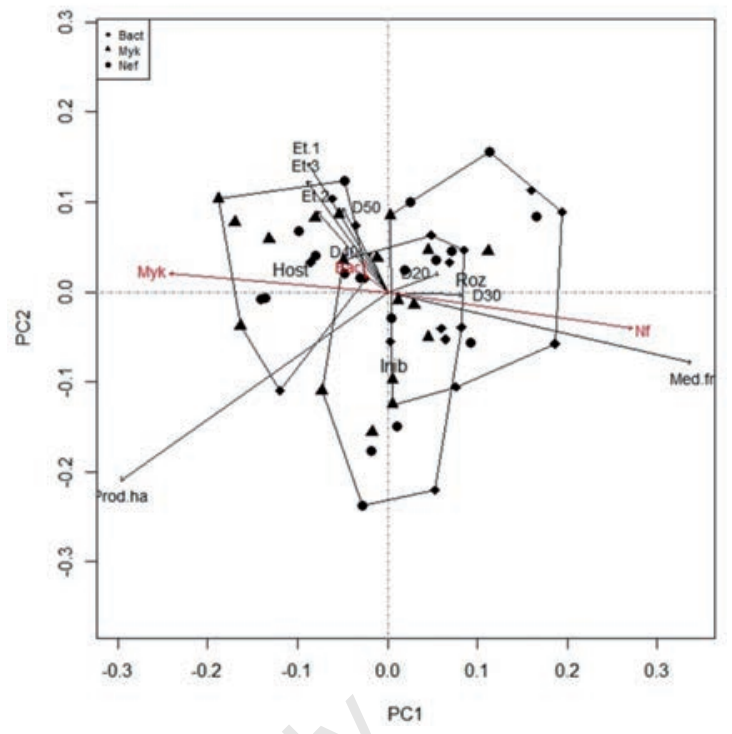

Figure 2. Principal component analysis of interaction between the experimental factors and aboveground development.

Table 3. Correlation of plants development with the experimental factors.

\begin{tabular}{|c|c|c|c|c|c|c|c|c|c|}
\hline \multicolumn{2}{|l|}{ Development } & Host & Roz & Inib & Conv & Neonv & Nf & Myk & Bact \\
\hline \multirow[t]{9}{*}{ Aboveground } & D20 & $-0.80^{*}$ & 0.08 & $0.71^{*}$ & -0.02 & 0.02 & -0.19 & 0.11 & 0.08 \\
\hline & D30 & $-0.80 *$ & 0.15 & $0.64^{*}$ & -0.08 & 0.08 & -0.21 & 0.16 & 0.05 \\
\hline & D40 & $-0.29 *$ & 0.11 & 0.18 & -0.17 & 0.17 & $-0.29 *$ & 0.18 & 0.10 \\
\hline & D50 & 0.24 & 0.09 & $-0.32 *$ & -0.10 & 0.10 & $-0.28 *$ & 0.14 & 0.14 \\
\hline & Et.1 & 0.26 & -0.12 & -0.13 & 0.11 & -0.11 & $-0.71^{*}$ & $0.38 *$ & $0.33^{*}$ \\
\hline & Et.2 & 0.02 & -0.21 & 0.18 & -0.22 & 0.22 & $-0.51^{*}$ & 0.24 & 0.26 \\
\hline & Et.3 & -0.08 & -0.23 & $0.30^{*}$ & -0.07 & 0.07 & $-0.85^{*}$ & $0.40^{*}$ & $0.44^{*}$ \\
\hline & Prod & 0.00 & $-0.35^{*}$ & $0.35^{*}$ & -0.08 & 0.08 & $-0.39 *$ & 0.24 & 0.15 \\
\hline & Av.fr & $-0.81^{*}$ & $0.44^{*}$ & $0.36^{*}$ & -0.03 & 0.03 & -0.02 & -0.13 & 0.15 \\
\hline \multirow[t]{18}{*}{ Belowground } & Cdeg15 & 0.03 & -0.03 & 0.00 & -0.10 & 0.10 & $-0.49^{*}$ & $0.60 *$ & -0.12 \\
\hline & al5 & -0.14 & 0.01 & 0.13 & -0.18 & 0.18 & $-0.61^{*}$ & $0.72 *$ & -0.12 \\
\hline & $\mathrm{A} 15$ & -0.02 & -0.02 & 0.04 & -0.11 & 0.11 & $-0.48 *$ & $0.66^{*}$ & -0.19 \\
\hline & Cdeg35 & 0.04 & -0.02 & -0.01 & 0.04 & -0.04 & $-0.53^{*}$ & $0.92 *$ & $-0.40^{*}$ \\
\hline & a35 & 0.02 & -0.06 & 0.04 & -0.04 & 0.04 & $-0.65^{*}$ & $0.92 *$ & $-0.28 *$ \\
\hline & A35 & 0.04 & -0.06 & 0.02 & 0.01 & -0.01 & $-0.54^{*}$ & $0.93^{*}$ & $-0.40 *$ \\
\hline & Cdeg55 & 0.03 & -0.12 & 0.10 & 0.09 & -0.09 & $-0.46^{*}$ & $0.78^{*}$ & $-0.33^{*}$ \\
\hline & a 55 & 0.03 & -0.15 & 0.12 & 0.03 & -0.03 & $-0.67^{*}$ & $0.82 *$ & -0.16 \\
\hline & $\mathrm{A} 55$ & 0.05 & -0.16 & 0.11 & 0.07 & -0.07 & $-0.51^{*}$ & $0.81^{*}$ & $-0.31^{*}$ \\
\hline & Cdeg75 & -0.03 & -0.02 & 0.04 & -0.15 & 0.15 & $-0.61^{*}$ & $0.84 *$ & -0.25 \\
\hline & a75 & 0.08 & -0.06 & -0.02 & -0.18 & 0.18 & $-0.66^{*}$ & $0.72 *$ & -0.07 \\
\hline & A75 & 0.00 & -0.02 & 0.02 & -0.16 & 0.16 & $-0.60^{*}$ & $0.84^{*}$ & -0.25 \\
\hline & Cdeg95 & 0.11 & -0.09 & -0.02 & 0.05 & -0.05 & $-0.66^{*}$ & $0.65 *$ & 0.00 \\
\hline & a95 & 0.21 & -0.19 & -0.01 & -0.08 & 0.08 & $-0.59 *$ & $0.55^{*}$ & 0.03 \\
\hline & A95 & 0.13 & -0.15 & 0.02 & -0.01 & 0.01 & $-0.64^{*}$ & $0.71 *$ & -0.08 \\
\hline & Cdeg115 & 0.15 & -0.12 & -0.02 & -0.09 & 0.09 & $-0.88^{*}$ & $0.67 *$ & 0.21 \\
\hline & al15 & 0.02 & -0.03 & 0.01 & -0.10 & 0.10 & $-0.79^{*}$ & $0.72 *$ & 0.06 \\
\hline & Al15 & 0.12 & -0.12 & 0.00 & -0.10 & 0.10 & $-0.83^{*}$ & $0.77^{*}$ & 0.05 \\
\hline
\end{tabular}

D, increase in height of plants $\left(\mathrm{cm}^{-1}\right)$ at 20,30,40,50 days from transplantation; Et 1,2,3, fructification at each plant floor (\%); Prod, production (t ha $\left.{ }^{-1}\right)$; Av.fr, average mass of tomatoes fruits ( $\mathrm{g}$ fruit ${ }^{-1}$ ); a, A, Cdeg, mycorrhizal parameters (\%); $15,35,55,75,95,115$ - days from plantation. ${ }^{*} \mathrm{P}<0.05$.

Table 4. Stability of clusters for aboveground development.

\begin{tabular}{llllllllll} 
Cluster & D20 & D30 & D40 & D50 & Et1 & Et2 & Et3 & Prod & Av.fr \\
A1 & $12.37^{\mathrm{b}}$ & $15.16^{\mathrm{b}}$ & $18.44^{\mathrm{a}}$ & $25.00^{\mathrm{a}}$ & $67.51^{\mathrm{a}}$ & $69.50^{\mathrm{a}}$ & $59.72^{\mathrm{ab}}$ & $135.42^{\mathrm{ab}}$ & $203.64^{\mathrm{b}}$ \\
B2 & $15.29^{\mathrm{a}}$ & $19.54^{\mathrm{a}}$ & $19.39^{\mathrm{a}}$ & $23.87^{\mathrm{a}}$ & $64.23^{\mathrm{a}}$ & $67.09^{\mathrm{a}}$ & $56.12^{\mathrm{b}}$ & $118.37^{\mathrm{b}}$ & $254.17^{\mathrm{a}}$ \\
\hline B3 & $16.11^{\mathrm{a}}$ & $21.04^{\mathrm{a}}$ & $19.21^{\mathrm{a}}$ & $24.18^{\mathrm{a}}$ & $66.25^{\mathrm{a}}$ & $70.17^{\mathrm{a}}$ & $63.12^{\mathrm{a}}$ & $143.33^{\mathrm{a}}$ & $273.97^{\mathrm{a}}$ \\
\hline
\end{tabular}

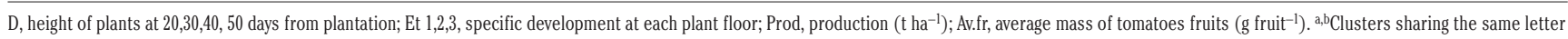
are not significantly different at $\mathrm{P}<0.05$ in Tukey HSD test. 
fertilisers in spatial separation of experimental variants (Figure 3). The supplementary mycorrhization is visible even at the separation in 2 clusters, and at splitting the dendrogram in 3 clusters, it is noticed that each fertilisation represents a homogenous cluster. The similarity between unfertilised control and bacterial inoculation in cluster D is owed to the lack of mycorrhizal inoculum in the fertilisation formula, which sets a reduced development potential of symbiosis compared to the variants in cluster 4 . The mycorrhization differences are visible over the monitoring period, but with statistical assurance only concerning the arbuscularity (Table 6). The supplementary mycorrhization acts as a trigger in the first 5 sequences of vegetation and maintains, with slight fluctuations, the percentage of arbuscules in the mycorrhized fragments at approximately $50 \%$ over the entire experimental period. Starting with the sequence of 35 days after transplantation, the arbuscularity in fragments increases at $50 \%$ in the non-fertilised variants and remain at this level. This phenomenon indicated the mycorrhizal native potential of the soil and the antagonism between the inoculated species and those from the indigenous mycoflora. The exogenous bacteria affect the dynamics of native mycorrhizas and reduces with $10 \%$ the arbuscularity in fragments over the entire vegetation period, compared to the unfertilised variants. The arbuscular circuit in the radicular system highlights the strong potential of cellular colonisation of the indigenous mycoflora, the differences being statistically ensured in the middle and the end of vegetation period. The treatments do not manage to increase the arbuscularity levels, bacterial inoculum maintaining this parameter under the 3\% level. Although the mycorrhization frequency is of $100 \%$, the colonisation intensity is under $10 \%$, with higher values in the second part of the vegetation period. The differences between the variants are insignificant. Unlike the aboveground development, the mycorrhization of radicular systems is more depended on the fertilisation and less on the variety taken into study (Figure 4, Table 7). The variance explained by the axes sum up $49.32 \%$ (PC1 $29.59 \%$ and

Table 5. Variance explained and factor loadings for aboveground development principal component analysis.

\begin{tabular}{|c|c|c|c|c|c|}
\hline & PC1 & PC2 & $r^{2}$ & $\operatorname{Pr}(>r)$ & Significance \\
\hline Host & -0.92 & 0.40 & 0.67 & 0.001 & $* * *$ \\
\hline Roz & 0.99 & 0.12 & 0.37 & 0.001 & $* * *$ \\
\hline Inib & 0.32 & -0.95 & 0.17 & 0.01 & $* *$ \\
\hline Conv & 0.57 & 0.82 & 0.00 & 0.933 & \\
\hline Nconv & -0.57 & -0.82 & 0.00 & 0.933 & \\
\hline $\mathrm{Nf}$ & 0.99 & -0.14 & 0.12 & 0.035 & $*$ \\
\hline Myk & -1.00 & 0.08 & 0.09 & 0.078 & \\
\hline Bact & -0.81 & 0.58 & 0.00 & 0.961 & \\
\hline
\end{tabular}

PC, principal component; $\mathrm{PC} 1,56.21 \% ; \mathrm{PC} 2,24.83 \% .{ }^{*} \mathrm{P}<0.05 ; * * \mathrm{P}<0.01 ; * * \mathrm{P}<0.001$.

Table 6. Stability of clusters for belowground development.

\begin{tabular}{|c|c|c|c|c|c|c|}
\hline Cluster & al5 & a35 & a55 & $\mathrm{a} 75$ & a95 & al15 \\
\hline $\mathrm{C} 4$ & $47.02^{\mathrm{a}}$ & $51.13^{a}$ & $49.65^{\mathrm{a}}$ & $49.00^{\mathrm{a}}$ & $50.67^{\mathrm{ab}}$ & $49.68^{a}$ \\
\hline D5 & $38.97^{\mathrm{a}}$ & $50.25^{\mathrm{a}}$ & $50.31^{\mathrm{a}}$ & $49.81^{\mathrm{a}}$ & $53.40^{\mathrm{a}}$ & $49.79^{\mathrm{a}}$ \\
\hline D6 & $37.83^{\mathrm{a}}$ & $40.24^{a}$ & $40.23^{a}$ & $43.15^{\mathrm{a}}$ & $42.02^{b}$ & $41.23^{\mathrm{a}}$ \\
\hline Cluster & $\mathrm{A} 15$ & A35 & A55 & A75 & A95 & A115 \\
\hline $\mathrm{C} 4$ & $1.95^{\mathrm{a}}$ & $2.56^{\mathrm{a}}$ & $2.25^{\mathrm{ab}}$ & $3.65^{\mathrm{a}}$ & $4.04^{\mathrm{a}}$ & $4.96^{\mathrm{ab}}$ \\
\hline D5 & $2.48^{\mathrm{a}}$ & $2.64^{\mathrm{a}}$ & $2.71^{\mathrm{a}}$ & $3.41^{\mathrm{a}}$ & $4.36^{\mathrm{a}}$ & $5.04^{\mathrm{a}}$ \\
\hline D6 & $1.59^{a}$ & $1.60^{\mathrm{a}}$ & $1.47^{\mathrm{b}}$ & $2.18^{\mathrm{a}}$ & $2.37^{\mathrm{a}}$ & $2.88^{\mathrm{b}}$ \\
\hline Cluster & Cdeg15 & Cdeg35 & Cdeg55 & Cdeg75 & Cdeg95 & Cdeg115 \\
\hline $\mathrm{C} 4$ & $4.55^{\mathrm{a}}$ & $4.51^{\mathrm{a}}$ & $4.20^{\mathrm{a}}$ & $6.74^{\mathrm{a}}$ & $6.95^{\mathrm{a}}$ & $9.21^{\mathrm{a}}$ \\
\hline D5 & $4.22^{\mathrm{a}}$ & $4.63^{\mathrm{a}}$ & $4.75^{\mathrm{a}}$ & $6.21^{\mathrm{a}}$ & $7.32^{\mathrm{a}}$ & $9.28^{\mathrm{a}}$ \\
\hline D6 & $3.68^{\mathrm{a}}$ & $3.56^{\mathrm{a}}$ & $3.43^{\mathrm{a}}$ & $4.44^{\mathrm{a}}$ & $5.18^{a}$ & $6.12^{\mathrm{a}}$ \\
\hline
\end{tabular}

a, A, Cdeg, mycorrhizal parameters; $15,35,55,75,95,115$ - days from plantation. ab, Cluster sharing the same letter are not significantly different $\mathrm{P}<0.05$ in Tukey HSD test.

Table 7. Variance explained and factor loadings for belowground development principal component analysis.

\begin{tabular}{|c|c|c|c|c|c|}
\hline & PC1 & PC2 & $r^{2}$ & $\operatorname{Pr}(>\mathrm{r})$ & Significance \\
\hline Host & -0.20 & 0.98 & 0.10 & 0.061 & \\
\hline Roz & 0.07 & -1.00 & 0.04 & 0.358 & \\
\hline Inib & 0.44 & -0.90 & 0.01 & 0.72 & \\
\hline Conv & -0.51 & 0.86 & 0.07 & 0.158 & \\
\hline Nconv & 0.51 & -0.86 & 0.07 & 0.158 & \\
\hline $\mathrm{Nf}$ & -0.89 & -0.46 & 0.73 & 0.001 & $* * *$ \\
\hline Myk & 0.94 & 0.34 & 0.59 & 0.001 & $* * *$ \\
\hline Bact & 0.22 & 0.97 & 0.02 & 0.642 & \\
\hline
\end{tabular}

PC, principal component; PC1, 29.59\%; PC2, 19.73\%. ***P $<0.001$. 
PC2 19.73\%). In the absence of fertilisation, strong development of the mycorrhization is spontaneous and it is appearing from the stage of 75 days to the 95 days from the planting. The treatments act as a separation axis between the supplementary and natural mycorrhization, the direction of the two gradients being antagonistic. The correlation between the mycorrhization parameters and the aboveground development is obvious at the analysis of vegetative stages (Table 8). The third stage is significantly correlated with all the mycorrhizal parameters, indifferent of the vegetation phase, which indicates a constant stimulation effect of the symbiotic input. The base stages are strongly influenced by the mycorrhizal value at the end of the vegetation period, and in a reduced level by the values of the intermediary periods (Table 8). The production grows due to arbuscularity in the period 35-55 days from planting and of all mycorrhizal structures at the end of vegetation period.

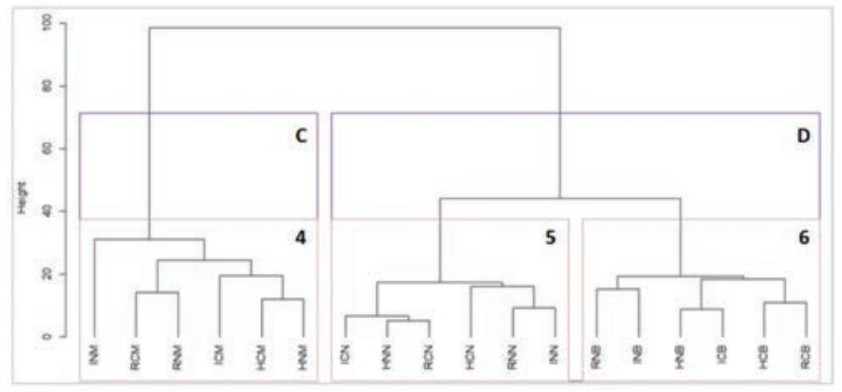

Figure 3. Dendrogram of belowground development. Legend of code letters is as follows: first letter: H, R, I - plant genotype; second letter: C, N - type of crop system; third letter: N, M, B - type of fertilisation.
The average of fruit weights is a variety character and is weakly correlated with the level of mycorrhization, in general the symbiosis slightly decreasing this parameter. The phenomenon is based on the capacity to balance the nutritive elements transfers by the fungus in the plant system and equalising the average of produces fruits.

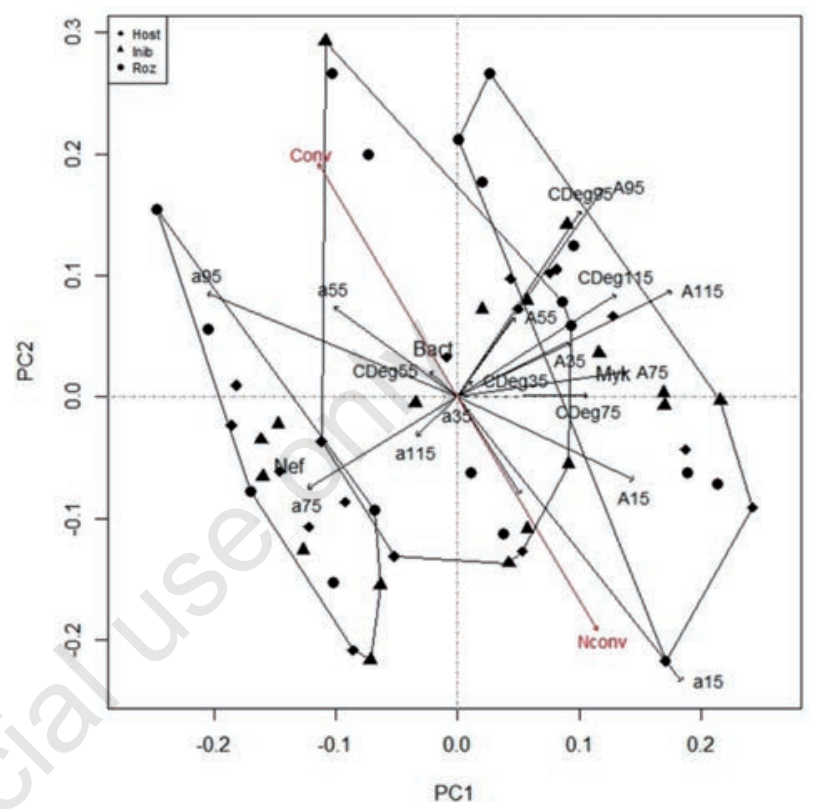

Figure 4. Principal component analysis of interaction between the experimental factors and belowground development.

Table 8. Correlation of above- and belowground development parameters.

\begin{tabular}{|c|c|c|c|c|c|}
\hline & Et. 1 & Et. 2 & Et. 3 & Prod & Av.fir \\
\hline CDeg15 & $0.46^{*}$ & 0.23 & $0.51^{*}$ & -0.01 & -0.08 \\
\hline al5 & $0.49 *$ & $0.39 *$ & $0.54^{*}$ & 0.23 & 0.06 \\
\hline A15 & $0.42 *$ & 0.26 & $0.48^{*}$ & 0.06 & -0.05 \\
\hline CDeg35 & $0.40^{*}$ & $0.28 *$ & $0.46^{*}$ & 0.23 & -0.13 \\
\hline a35 & $0.49 *$ & $0.32 *$ & $0.55^{*}$ & $0.34^{*}$ & -0.12 \\
\hline A35 & $0.42^{*}$ & $0.29 *$ & $0.48^{*}$ & $0.27^{*}$ & -0.15 \\
\hline CDeg55 & $0.30^{*}$ & $0.33^{*}$ & $0.46^{*}$ & $0.27^{*}$ & -0.09 \\
\hline $\mathrm{a} 55$ & $0.43^{*}$ & $0.28^{*}$ & $0.65^{*}$ & $0.31^{*}$ & -0.11 \\
\hline $\mathrm{A} 55$ & $0.34^{*}$ & $0.32 *$ & $0.51^{*}$ & $0.29 *$ & -0.12 \\
\hline CDeg75 & $0.39 *$ & $0.41^{*}$ & $0.54^{*}$ & $0.31^{*}$ & -0.02 \\
\hline a75 & $0.46^{*}$ & $0.34^{*}$ & $0.59 *$ & 0.21 & -0.11 \\
\hline A75 & $0.39 *$ & $0.36^{*}$ & $0.53^{*}$ & 0.26 & -0.05 \\
\hline CDeg95 & $0.41^{*}$ & $0.29 *$ & $0.51^{*}$ & $0.42 *$ & -0.06 \\
\hline a95 & $0.50^{*}$ & $0.31^{*}$ & $0.51^{*}$ & $0.31^{*}$ & -0.18 \\
\hline A95 & $0.42^{*}$ & $0.33^{*}$ & $0.52 *$ & $0.43^{*}$ & -0.10 \\
\hline CDeg115 & $0.65^{*}$ & $0.46^{*}$ & $0.77^{*}$ & $0.30^{*}$ & -0.13 \\
\hline al15 & $0.60^{*}$ & $0.49 *$ & $0.67^{*}$ & $0.38 *$ & 0.04 \\
\hline Al15 & $0.63^{*}$ & $0.45^{*}$ & $0.74^{*}$ & $0.31^{*}$ & -0.10 \\
\hline
\end{tabular}

Et 1,2,3, fructification at each plant floor (\%); Prod, production (t ha ${ }^{-1}$ ); Av.fr, average mass of tomatoes fruits ( $(\mathrm{g}$ fruit-1); a, A, Cdeg, mycorrhizal parameters (\%); $15,35,55,75,95,115$ - days from plantation. *P<0.05. 


\section{Discussion}

The supplementary mycorrhization and bacterial inoculation act towards stimulating the development of levels 1 and 3 of the plants, as reported before in other studies (Candido et al., 2013; Candido et al., 2015; Kim et al., 1997). Among the tested fertilisers, the bacterial inoculum had the lowest effect over the development with a gradient towards the Hostati variety and both of them are integrated in the interaction variety-treatment complex. The mycorrhization and the lack of fertilisation act in different directions, approximately antagonistic.

The use of the mycorrhizal biopreparates stimulates the development of the variety Hostati while the Roz variety is sensitive in the lack of fertilisation. Hostati variety is mostly adapted for productivity, and Roz variety for higher weight averages of fruits. For the Inimă de bou genotype there are variants which give results in both conditions. This variety, as yield and average weight of fruits, has a moderate reaction towards the experimental factors interactions, located in the center of principal components ordination.

Inoculated bacteria interferes significantly with the symbiosis only in the initial plant development stages, previously reported in several researches (Artursson et al., 2006; Hodge and Storer, 2015; Jung et al., 2012; Pivato et al., 2009). These considerations set the separate analysis of above and under-ground characters, as proposed by Rillig et al. (2008), based on reaction of non-AMF genotypes to experimental variables. Separation of the experimental variants in 3 clusters highlights strongly the difference of reactions of the varieties to fertilisation in conventional and unconventional culture system, similar to reported results by Liu et al. (2014). Using conventional and unconventional treatments do not set strongly different developments, the 3 varieties having a homogenous response to these actions, as reported by Cavagnaro et al. (2006, 2008).

The gradient of supplementary mycorrhization and natural mycorrhization acts in different directions, the level of parameters highlighting the antagonism in the soil. The varieties sensitivity to the experimental factors is higher at Hostati and lower for Roz and Inimă de bou. The inoculated bacteria reduces the level of mycorrhization in the stage of 35-55 days from planting, while the supplementary mycorrhization increases the arbuscularity in the radicular system and the degree of colonisation.

\section{Conclusions}

The aboveground development is a character dependent of the variety, while the mycorrhizal development is dependent on the experimental factors. Biofertilisers inoculation is visible in the extent of mycorrhizas in root system, each of them stimulating a specific homogenous development. Exogenous mycorrhizas have a high potential to compete with the indigenous mycorrhizal flora. The exogenous bacteria affects the dynamics of native mycorrhizas and reduces the arbuscularity over the entire vegetation period. Additional mycorrhization leads to reduced values for the degree of colonisation, but produces high values of arbuscules in the fragments colonised, which enhances the transfer of nutrients to plants.

\section{References}

Abbas MT, Hamza MA, Youssef HH, Youssef GH, Fayez M, Monib M, Hegazi NA, 2014. Bio-preparates support the productivity of potato plants grown under desert farming conditions of north Sinai: Five years of field trials. J. Adv. Res. 5:41-8.

Ahmed EA, Hassan, EA, El Tobgy KMK, Ramadan EM, 2014. Evaluation of rhizobacteria of some medicinal plants for plant growth promotion and biological control. Ann. Agric. Sci. 59:273-80.

Artursson V, Finlay RD, Jansson JK, 2006. Interactions between arbuscular mycorrhizal fungi and bacteria and their potential for stimulating plant growth. Environ. Microbiol. 8:1-10.

Barrière V, Lecompte F, Nicot PC, Maisonneuve B, Tchamitchian M, Lescourret F, 2014. Lettuce cropping with less pesticides. A review. Agron. Sust. Develop. 34:175-98.

Bashan Y, de-Bashan LE, Prabhu SR, Hernandez JP, 2014. Advances in plant growth-promoting bacterial inoculant technology: formulations and practical perspectives (1998-2013). Plant Soil 378:1-33.

Bonfante P, Genre A, 2008. Plants and arbuscular mycorrhizal fungi: an evolutionary-developmental perspective. Trends Plant Sci. 13:492-8.

Brundrett MC, Ashwath N, 2013. Glomeromycotan mycorrhizal fungi from tropical Australia III. Measuring diversity in natural and disturbed habitats. Plant Soil 370:419-33.

Candido V, Campanelli G, D'Addabbo T, Castronuovo D, Perniola M, Camele I, 2015. Growth and yield promoting effect of artificial mycorrhization on field tomato at different irrigation regimes. Scientia Horticult. 187:35-43.

Candido V, Campanelli G, D'Addabbo T, Castronuovo D, Renco M, Camele I, 2013. Growth and yield promoting effect of artificial mycorrhization combined with different fertiliser rates on field-grown tomato. Ital. J. Agron. 8:22.

Cavagnaro TR, Jackson LE, Six J, Ferris H, Goyal S, Asami D, Scow KM, 2006. Arbuscular mycorrhizas, microbial communities, nutrient availability, and soil aggregates in organic tomato production. Plant Soil 282:209-25.

Cavagnaro TR, Langley AJ, Jackson LE, Smukler SM, Koch GW, 2008. Growth, nutrition, and soil respiration of a mycorrhizadefective tomato mutant and its mycorrhizal wild-type progenitor. Funct. Plant Biol. 35:228-35.

Conversa G, Lazzizera C, Bonasia A, Elia A, 2012. Yield and phosphorus uptake of a processing tomato crop grown at different phosphorus levels in a calcareous soil as affected by mycorrhizal inoculation under field conditions. Biol. Fertil. Soils 49:691-703.

de Mendiburu F, 2014. Agricolae: Statistical Procedures for Agricultural Research. R package version 1.2-1. Available from: http://CRAN.R-project.org/package=agricolae

Dotaniya ML, Meena VD, 2015. Rhizosphere effect on nutrient availability in soil and its uptake by plants: a review. P. Natl. Acad. Sci. India B 85:1-12.

du Jardin P, 2015. Plant biostimulants: definition, concept, main categories and regulation. Scientia Horticult. 196:3-14.

Egamberdieva D, Shrivastava S, Varma A, 2015. Plant-growthpromoting rhizobacteria (PGPR) and medicinal plants (Vol. 42). Springer, Amsterdam, The Netherlands.

Ehrmann J, Ritz K, 2014. Plant: soil interactions in temperate multi-cropping production systems. Plant Soil 376:1-29.

Fahad S, Hussain S, Matloob A, Khan F, Khaliq A, Saud S, Hassan S, Shan D, Khan F, Ullah N, Faiq M, Khan M, Tareen A, Khan 
A, Ullah A, Ullah N, Huang J, 2015. Phytohormones and plant responses to salinity stress: a review. Plant Growth Regul. 75: 391-404.

Fritz M, Jakobsen I, Lyngkjær MF, Thordal-Christensen H, PonsKühnemann J, 2006. Arbuscular mycorrhiza reduces susceptibility of tomato to Alternaria solani. Mycorrhiza 16:413-9.

Garg N, Chandel S, 2010. Arbuscular mycorrhizal networks: process and functions. A review. Agron. Sustain. Develop. 30:581-99.

Garg N, Pandey R, 2015. Effectiveness of native and exotic arbuscular mycorrhizal fungi on nutrient uptake and ion homeostasis in salt-stressed Cajanus cajan L. (Millsp.) genotypes. Mycorrhiza 25:165-80.

Gianinazzi S, Gollotte A, Binet MN, van Tuinen D, Redecker D, Wipf D, 2010. Agroecology: the key role of arbuscular mycorrhizas in ecosystem services. Mycorrhiza 20:519-30.

Harrell FE Jr, Dupont C, 2015. Hmisc. R package version 3.15-0. Available from: http://CRAN.R-project.org/package=Hmisc

Helgason T, Fitter AH, 2009. Natural selection and the evolutionary ecology of the arbuscular mycorrhizal fungi (Phylum Glomeromycota). J. Experiment. Bot. 60:2465-80.

Hodge A, Storer K, 2015. Arbuscular mycorrhiza and nitrogen: implications for individual plants through to ecosystems. Plant Soil 386:1-19.

Hoeksema JD, Chaudhary VB, Gehring CA, Johnson NC, Karst J, Koide RT, Pringle A, Zabinski C, Bever JD, Moore JC, Wilson GWT, Klironomos JN, Umbanhowar J, 2010. A metaanalysis of context-dependency in plant response to inoculation with mycorrhizal fungi. Ecol. Lett. 13:394-407.

Jayne B, Quigley M, 2014. Influence of arbuscular mycorrhiza on growth and reproductive response of plants under water deficit: a meta-analysis. Mycorrhiza 24:109-19.

Jung SC, Martinez-Medina A, Lopez-Raez JA, Pozo MJ, 2012. Mycorrhiza-induced resistance and priming of plant defenses. J. Chem. Ecol. 38:651-64.

Kim KY, Jordan D, McDonald GA, 1997. Effect of phosphate-solubilizing bacteria and vesicular-arbuscular mycorrhizae on tomato growth and soil microbial activity. Biol. Fertil. Soils 26:79-87.

Koltai H, Kapulnik Y, 2010. Arbuscular mycorrhizas: physiology and function. Springer Science \& Business Media, Amsterdam, The Netherlands.

Lambers H, Mougel C, Jaillard B, Hinsinger P, 2009. Plantmicrobe-soil interactions in the rhizosphere: an evolutionary perspective. Plant Soil 321:83-115.

Lareen A, Burton F, Schäfer P, 2016. Plant root-microbe communication in shaping root microbiomes. Plant Molec. Biol. 90:1-13.

Lemanceau P, Maron PA, Mazurier S, Mougel C, Pivato B, Plassart P, Ranjard L, Revellin C, Tardy V, Wipf D, 2015. Understanding and managing soil biodiversity: a major challenge in agroecology. Agronom. Sustain. Develop. 35:67-81.

Liu W, Zheng C, Fu Z, Gai J, Zhang J, Christie P, Li X, 2014. Facilitation of seedling growth and nutrient uptake by indigenous arbuscular mycorrhizal fungi in intensive agroecosytems. Biol. Fertil. Soils 50:381-94.

Maechler M, Rousseeuw P, Struyf A, Hubert M, Hornik K, 2015. cluster: Cluster Analysis Basics and Extensions. R package version 2.0.1.

Matsushita Y, Bao Z, Kurose D, Okada H, Takemoto S, Sawada A, Nagase H, Takano M, Murakami H, Koitabashi M, Yoshida S, Saito M, Sano T, Yoshida S, 2015. Community structure, diversity, and species dominance of bacteria, fungi, and nematodes from naturally and conventionally farmed soil: a case study on
Japanese apple orchards. Organic Agric. 5:11-28.

Moënne-Loccoz Y, Mavingui P, Combes C, Normand P, Steinberg C, 2015. Microorganisms and biotic interactions. In: Bertrand, J.-C., Caumette, P., Lebaron, P., Matheron, R., Normand, P., Sime-Ngando, T. (eds.) Environmental microbiology: fundamentals and applications. Springer, Amsterdam, The Netherlands. pp. 395-444.

Montaño NM, Alarcón A, Camargo-Ricalde SL, HernándezCuevas LV, Álvarez-Sánchez J, González-Chávez MDCA, Gavito ME, Sánchez-Gallen I, Ramos-Zapata J, Guadarrama P, Maldonado-Mendoza IE, Castillo-Argüero S, García-Sánchez R, Trejo D, Ferrera-Cerrato R, 2012. Research on arbuscular mycorrhizae in Mexico: an historical synthesis and future prospects. Symbiosis 57:111-26.

Oksanen J, Blanchet FG, Kindt R, Legendre P, Minchin PR, O'Hara RB, Simpson GL, Solymos P, Henry M, Stevens H, Wagner H, 2015. vegan: Community Ecology Package. R package version 2.2-1. Available from: http://CRAN.R-project.org/package $=$ vegan

Pandya U, Maheshwari DK, Saraf M, 2014. Assessment of ecological diversity of rhizobacterial communities in vermicompost and analysis of their potential to improve plant growth. Biologia 69:968-76.

Park S, Seo YS, Hegeman AD, 2014. Plant metabolomics for plant chemical responses to belowground community change by climate change. J. Plant Biol. 57:137-49.

Paul D, Lade H, 2014. Plant-growth-promoting rhizobacteria to improve crop growth in saline soils: a review. Agron. Sustain. Develop. 34:737-52.

Pivato B, Offre P, Marchelli S, Barbonaglia B, Mougel C, Lemanceau P, Berta G, 2009. Bacterial effects on arbuscular mycorrhizal fungi and mycorrhiza development as influenced by the bacteria, fungi, and host plant. Mycorrhiza 19:81-90.

Prashar P, Kapoor N, Sachdeva S, 2014. Rhizosphere: its structure, bacterial diversity and significance. Rev. Environ. Sci. Bio/Technol. 13:63-77.

Raviv M, 2010. The use of mycorrhiza in organically-grown crops under semi arid conditions: a review of benefits, constraints and future challenges. Symbiosis 52:65-74.

Rillig MC, Ramsey PW, Gannon JE, Mummey DL, Gadkar V, Kapulnik Y, 2008. Suitability of mycorrhiza-defective mutant/wildtype plant pairs (Solanum lycopersicum L. cv Micro-Tom) to address questions in mycorrhizal soil ecology. Plant Soil 308:267-75.

Rillig MC, Wendt S, Antonovics J, Hempel S, Kohler J, Wehner J, Caruso T, 2014. Interactive effects of root endophytes and arbuscular mycorrhizal fungi on an experimental plant community. Oecologia 174:263-70.

RStudio Team, 2015. RStudio: Integrated Development for R. RStudio, Inc., Boston, MA, USA. Available from: http://www.rstudio.com/

Shrivastava G, Ownley BH, Augé RM, Toler H, Dee M, Vu A, Köllner TG, Chen F, 2015. Colonization by arbuscular mycorrhizal and endophytic fungi enhanced terpene production in tomato plants and their defense against a herbivorous insect. Symbiosis 65:65-74.

Stoian V, Vidican R, Rotar I, Păcurar F, 2014. Establishment of variations in mycorrhizal colonization produced by overlapping a treatment with zinc sulfate over differentiated fertilization. Bull. Univ. Agric. Sci. Vet. Medicine Cluj-Napoca Agric. 71:385-6.

Taffouo VD, Ngwene B, Akoa A, Franken P, 2014. Influence of phosphorus application and arbuscular mycorrhizal inocula- 
tion on growth, foliar nitrogen mobilization, and phosphorus partitioning in cowpea plants. Mycorrhiza 24:361-8.

Treseder KK, 2013. The extent of mycorrhizal colonization of roots and its influence on plant growth and phosphorus content. Plant Soil 371:1-13.

Verma JP, Jaiswal DK, Sagar R, 2014. Pesticide relevance and their microbial degradation: a-state-of-art. Rev. Environ. Sci. Bio/Technol. 13:429-66.

Vicente-Sánchez J, Nicolás E, Pedrero F, Alarcón JJ, MaestreValero JF, Fernández F, 2014. Arbuscular mycorrhizal symbiosis alleviates detrimental effects of saline reclaimed water in lettuce plants. Mycorrhiza 24:339-48.

Watts-Williams SJ, Cavagnaro TR, 2014. Nutrient interactions and arbuscular mycorrhizas: a meta-analysis of a mycorrhizadefective mutant and wild-type tomato genotype pair. Plant Soil 384:79-92.

Wezel A, Casagrande M, Celette F, Vian JF, Ferrer A, Peigné J, 2014. Agroecological practices for sustainable agriculture. A review. Agron. Sustain. Develop. 34:1-20.

Yang T, Chen Y, Wang XX, Dai CC, 2013. Plant symbionts: keys to the phytosphere. Symbiosis 59:1-14. 